in the chemistry of carbohydrates, especially with regard to fructose and its derivatives.

In January 1924 Charing Cross Hospital and Medical School were fortunate and wise to secure his services as their first biochemist and lecturer in chemical pathology. His research activities were chiefly on quantitative aspects of chemical pathology.

In 1938, collaborating with H. W. C. Vines (later professor of pathology at Charing Cross Hospital) and others, ho assisted in writing The Adrenal Cortex and Intersexuality, and in 1952 he contributed a section to Recent Advances in Chemical Pathology. Apart from his main interests, many papers published by other Charing Cross staff acknowledge the assistance he gave to them in their work; indeed, his wise and balanced judgement was widely sought and appreciated by all who came into contact with him.

After the Second World War in 1947, when the preclinical school of Charing Cross was re-established, Prof. Patterson became responsible for the teaching not only of chemical pathology but also of biochemistry. In 1948 the University of London conferred on him the title of professor of chemical pathology. Just previous to his death the University of London eonferred on him the title of emeritus professor. He served as vice-dean of the Medical School from 1954 until 1957, served on the School Council, and for many years he was on the Board of Governors of the Hospital. He was a member of the Boards of Studies in Biochemistry and in Pathology and also of the Board of Pre-Clinical Studies of the University of London. After Charing Cross Hospital became associated (in 1959) with the West London and Fulham Hospitals, Prof. Patterson took on the additional responsibility of supervising their chemical laboratories.

Prof. Patterson's hobbies included gardening, and at his home in Chorley Wood he had a beautiful well-kept garden.

In 1926 he married Kathleen (née Thompson), who survives him. To her and his son we extend our sympathy. W. J. HAMILTON

\section{Prof. Wilfred Merchant}

Prof. Wilfred Merchant, professor of structural engineering in tho Faculty of Technology, University of Manchester, since 1957 , died on October 12 at the age of fifty-three after a long illness. He was educated at Manchester Grammar School and graduated with first-class honours in engineering scionce at Oxford in 1933. He then spent a number of years with a large firm of structural engineors.

He held a Commonwealth Fellowship at the Massachusetts Institute of Technology and obtained the degree of M.S. in 1939 with a thesis in soil mechanics. This work was the first rational advance of the general theory of consolidation of clay sinco its formulation in 1923, and it has recently been recognized that modern treatments of the subject are mathematically equivalent to that in Merchant's 1939 thesis.

During the Second World War, Prof. Merchant was employed by Metropolitan Vickers, Ltd., on the design of jet enginos. He made major contributions to the aerodynamic theory of flow through compressor blading. There was very littlo knowledge or experience of axial flow compressors at that time and his contributions played an important part in the design of jet engines.

Prof. Merchant joined the staff of the Manchester College of Science and Technology, Froulty of Technology in the University of Manchoster, in 1946, and was appointed reader in applied mechanics in 1951. After he joined the College his main interests were in the prediction of the failure load of structures taking account of the interaction of plasticity and stability. His intuition led him to propose an interaction formula which is now accepted and known by his name in the literature of the subject. During the past few years he developed computer techniques to carry out the erection calculations for the new Forth and Severn suspension bridges.

$\mathrm{He}$ was a member of the Institution of Structural Engineers, a member of the Institution of Civil Engineers and an associate member of the Institution of Mechanical Engineers and of the American Socioty of Civil Engineers. He served his professional institutions in many ways and was chairman of the Lancashire and Cheshire branch of the Institution of Structural Enginoers during 1960 61.

As a teacher he always found time to discuss problems individually with his students. His advice and guidance both to his students and to his colleagues were of great value. His contributions in three major branches of engineering are significant of his wide interests and keen analytical mind.

He leaves a wife, a son and a daughter. S. S. GiLI.

\section{Dr. Paul Müller}

PAUl MülleR, who was awarded the 1948 Nobel Prize for Physiology and Medicine, died in Basle on October 13, 1965 , after a short illness.

Paul Müller was born on January 12, 1899, in Olten. His father, who was on the staff of the Swiss Railways (SBB), moved soon afterwards to Basle, and Baslo became his home. There, after a spell as laboratory technician, he completed his studies at what was then the Obere Realschule (Modern High School) and then road chemistry at the University under Profs. Fichter and Rupe. In 1925 he took his doctorate with the highest honours, with a thesis on "The Chemical and Electrochemical Oxidation of Asymmetrical $m$-Xylidene and its Mono- and Di-methyl Derivatives". In the same year he joined Geigy as a research chemist, and he stayed with the firm for the rest of his life.

At first he worked on tanning, and developed a number of new synthetic tans. The problem of the preservation and disinfection of animal skins soon turned his attention to biology; and from 1935 he became more and more interested in pest control, a field with which organic chemists at that time had little concern. In the difficult years of the Second World War, when the battle for production was on, he developed and made available to Swiss farmers a mercury-free seed dressing. While still engaged on this development work his intercst was turning to insecticides, and with characteristic doggedness ho tosted largo numbers of chemical compounds, at first without success. But in 1939 his perseverance, coupled with his acute porception and methodical approach to all his experimental work, led him to the discovery of the insecticidal properties of dichloro-diphenyl trichlorethane, the active ingredient of DDT, which he developed for practical use. His achievement was to have discovered, at a critical time in the War, an insecticide with a contact and persistent action far and away superior to any other known product. His discovery was used both during and immediately after the War to protect millions of service-mon and civilian populations in all countries against epidemic diseases. Apart from their use in hygiene and agriculture, DDT insecticides are still extensively used to-day with success in many parts of the world against the Anopheles mosquito, the carrier of malaria. The significance of this great discovery was fittingly acknowledged by the award of the Nobel Prize for Physiology and Medicine in 1948.

In 1963 Müller received an honorary doctorate in the Faculty of Medicine at the University of Thessalonika, in recognition of the beneficial effect of DDT products in the Mediterranean area. He also became an honorary member of the Swiss Nature Research Society and of the Paris Society of Industrial Chemistry.

For all these many distinetions, Paul Müller remained what he had always been: a modest man, outwardly reserved, but with a passionate devotion to science. Even 